\title{
Consumer Picketing and the Single-Product Secondary Employer
}

Picketing by unions at the site of the employer with whom the union has a dispute (the primary employer) has generally been recognized as an acceptable means of publicizing a labor dispute.' Secondary picketing - that conducted at the site of a neutral employer $^{2}$ who does business with the primary employer ${ }^{3}$-has long been a source of controversy in the courts ${ }^{4}$ and in Congress, which has twice acted to restrict secondary picketing. ${ }^{5}$

'See, e.g., NLRB v. International Rice Milling Co., 341 U.S. 665 (1951). See also Goetz, Secondary Boycotts and the LMRA: A Path Through the Swamp, 19 U. KaN. L. Rev. 651, 656 (1971).

${ }^{2}$ A neutral employer is one who is not involved in the union's dispute with the primary employer. For a more detailed discussion of employer neutrality, see text and notes at notes 109-117 infra.

3 The term "secondary employer" will be used in this comment to refer to any party who does business with the primary employer, although this party may not be an employer-for example, the secondary business could be operated solely by the owner without employees. Usually, secondary employers will be customers or suppliers of the primary employer.

+ As one court noted:

The gravamen of a secondary boycott is that its sanctions bear, not upon the employer who alone is a party to the dispute, but upon some third party who has no concern in it. Its aim is to compel him to stop business with the employer in the hope that this will induce the employer to give in to his employees' demands.

IBEW, Local 501 v. NLRB, 181 F.2d 34, 37 (2d Cir. 1950) (Hand, C.J.), aff'd, 341 U.S. 694 (1951).

5 A prohibition on secondary boycotts was originally enacted in 1947 as part of the TaftHartley Act, Labor-Management Relations Act, Pub. L. No. 80-101, § 8(b)(4)(A), 61 Stat. 141 (1947) (current version at 29 U.S.C. $\$ 158(b)(4)(1976)$ ). See text and notes at notes 6468 infra.

In 1959, Congress passed the Landrum-Griffin amendments, which broadened the 1947 secondary boycott provision. Labor-Management Reporting and Disclosure Act (LMRDA) of 1959, Pub. L. No. 86-257, § 8(b)(4)(ii)(B), 73 Stat. 525 (codified at 29 U.S.C. § 158(b)(4)(ii)(B) (1976)). The amended section 8(b)(4) reads in pertinent part:

(b) It shall be an unfair labor practice for a labor organization or its agentsis-

(4) . . . (ii) to threaten, coerce, or restrain any person . . . , where an object thereof

(B) forcing or requiring any person to cease using, selling, handling, transporting, or otherwise dealing in the products of any other producer, processor, or manufacturer, or to cease doing business with any other person, . . . : Provided, That nothing contained in this clause (B) shall be construed to make unlawful . . . any primary strike or primary picketing;

. . Provided further, That for the purposes of this paragraph (4) only, nothing contained in such paragraph shall be construed to prohibit publicity, other than picketing, for the purpose of truthfully advising the public, including consumers . . , that a 
In NLRB v. Fruit and Vegetable Packers Local 670 (Tree Fruits Labor Relations Committee), ${ }^{6}$ the Supreme Court considered the applicability of the Landrum-Griffin secondary boycott provision, section $8(\mathrm{~b})(4)$ (ii)(B), to picketing addressed to customers of a secondary employer. The Court held that such picketing did not constitute an unfair labor practice if limited to a request to consumers not to purchase the primary employer's product, which was one of many products sold by the secondary employer. ${ }^{7}$ This situation, the Court suggested, was far removed from picketing directed at the secondary employer's business generally. ${ }^{8}$

The Tree Fruits opinion thus established the legality of secondary consumer picketing directed at a "struck" product when that product is one of many products sold by the secondary employer. The National Labor Relations Board and the courts, in construing Tree Fruits, have held that product picketing is illegal when the struck product is "merged" or integrated into the products of the secondary employer." In such a situation, a consumer cannot patronize the secondary employer while boycotting the primary employer's product. The Board and courts have thus concluded that merged-product picketing is unlawful because, if successful, it has the same effect as picketing directed at the secondary employer's business generally.

This comment will consider the legality of product picketing when sales of the struck product constitute all or most of the secondary employer's business. In that situation, the effect of picketing directed at that product becomes almost indistinguishable from picketing directed at the secondary enterprise generally. The comment first addresses the applicability of Tree Fruits, and concludes that the distinctions drawn by the Supreme Court in that case do not control in the single-product situation. ${ }^{10}$ The comment then examines the legislative history of the Landrum-Griffin amendments and argues that the major concern of Congress in passing the secondary boycott provision was the protection of neutral secondary employers. " This argument is bolstered by an analogy to the merged

product or products are produced by an employer with whom the labor organization has a primary dispute and are distributed by another employer . . . .

LMRDA § 8(b)(4)(ii)(B), 29 U.S.C. § 158(b)(4)(ii)(B) (1976).

- 377 U.S. 58 (1964).

7 Id. at 60 .

" Id. at 70. Picketing directed at the secondary employer's business generally, requesting customers not to patronize his business at all, is referred to as enterprise picketing.

- See text and notes at notes 118-138 infra.

16 See text and notes at notes 13.43 infra.

"See text and notes at notes $64-88$ infra. 
product doctrine, developed by the Board and lower courts after Tree Fruits. ${ }^{12}$ The comment concludes that Tree Fruits, read in light of the legislative history and subsequent lower court cases, suggests that secondary consumer picketing of single-product retailers violates the Act.

\section{The Tree Fruits Decision}

In Tree Fruits, a union of fruit and vegetable packers picketed Safeway grocery stores in Seattle that sold products (Washington State apples) packed by nonunion employees of the primary employer. The picket signs and handbills asked consumers not to purchase the apples, and stated that the union's dispute was with the primary employer and not Safeway. ${ }^{13}$ Safeway's employees continued to work and there was no obstruction of pick-ups or deliveries.

The National Labor Relations Board found that the picketing was designed to induce consumers not to buy the apples that Safeway purchased from the primary employer. ${ }^{14}$ "The natural and foreseeable result of such picketing, if successful, would be to force or require Safeway to reduce or discontinue altogether its purchases of such apples from the struck employers"; ${ }^{15}$ hence, the picketing did "threaten, coerce or restrain" the secondary employer in violation of section $8(\mathrm{~b})(4)(\mathrm{ii})(\mathrm{B}) .^{16}$

The court of appeals reversed. ${ }^{17}$ Section $8(\mathrm{~b})(4)$ (ii)(B), it held, did not ban all consumer picketing, but "only such conduct . . . as in fact threatens, coerces, or restrains secondary employers."18 It

12 See text and notes at notes 118-138 infra.

13 The picket signs stated, "To the Consumer: Non-Union Washington State apples are being sold at this store. Please do not purchase such apples. Thank you. Teamsters Local 760 , Yakima, Washington." The handbills read in part:

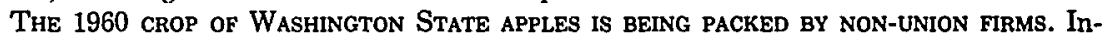
cluded in this non-union operation are twenty-six firms in the Yakima Valley with which there is a labor dispute....

In justice to these striking union workers who are attempting to protect their living standards and their right to engage in good-faith collective bargaining, we request that you DON'T BUY WASHINGTON STATE APPLES. . . .

This is not a strike against any store or market.

377 U.S. at 60 n.3.

14 Fruit \& Vegetable Packers Local 760 (Tree Fruits Labor Relations Comm.), 132 N.L.R.B. 1172, 1177 (1961), rev'd, 308 F.2d 311 (D.C. Cir. 1962), aff'd on other grounds, 377 U.S. 58 (1964).

is Id.

to Id. at $1172,1177-78$.

17 Fruit \& Vegetable Packers Local 760 v. NLRB (Tree Fruits Labor Relations Comm.), 308 F.2d 311 (D.C. Cir. 1962), aff'd on other grounds, 377 U.S. 58 (1964).

${ }^{18}$ Id. at 315 . 
noted that section 8(b)(4)(ii)(B), unlike other provisions in the labor statutes, did not explicitly prohibit all secondary picketing. ${ }^{19}$ Further, the court observed that a narrow reading of the statute was necessary to avoid serious first amendment questions that would be raised by an across-the-board ban. ${ }^{20}$ Since the picketing was peaceful and did not cause a work stoppage or interference with deliveries, the court concluded that the picketing would not violate the Act absent a showing that it had resulted in or was likely to result in "substantial economic impact" on the secondary employer. ${ }^{21}$ It remanded the case to the Board to allow evidence of economic impact to be taken and weighed. ${ }^{22}$

Although affirming the decision of the court of appeals, the Supreme Court adopted neither the Board's nor the court's interpretation of section $8(\mathrm{~b})(4)(\mathrm{ii})(\mathrm{B}) .^{23}$ Congress, said the Court, has consistently regulated peaceful picketing only to the extent necessary to deal with " "isolated evils" "24 or "clearly identified abuses" ing from particular forms of picketing used to achieve specific undesirable ends. ${ }^{26}$ In view of this policy, which it noted rested on first amendment concerns, ${ }^{27}$ the Court refused to acknowledge a congressional intent to ban picketing "unless "there is the clearest indication in the legislative history,' . . . that Congress intended to do so as regards the particular ends of the picketing under review." ${ }^{28}$ Such

19 Id. at 317. As an example the court cited section 8(b)(7), 29 U.S.C. $§ 158(b)$ (7) (1976), which explicitly prohibits picketing to force an employer to recognize an uncertified union.

${ }^{20}[\mathrm{I}] \mathrm{n}$ the absence of a showing that a substantial economic impact on the secondary employer has occurred or is likely to occur, we would be hard-put to find a constitutional justification for prohibiting a union from using picketing as the form of making "do not patronize" appeals, so long as the picketing is conducted in an entirely peaceful and non-coercive manner, is addressed solely to consumers, and has no side effects which might be a basis for distinguishing it from any other form of publicity.

308 F.2d at 317.

2I Id.

22 Id. at 318.

2377 U.S. 58 (1964). See generally Lewis, Consumer Picketing and the Court-The Questionable Yield of Tree Fruits, 49 MinN. L. REv. 479 (1965).

24377 U.S. at 62-63 (quoting NLRB v. Drivers Local Union No. 639, 362 U.S. 274, 284 (1960)).

${ }^{25}$ Id. at 67.

21 Id. at 62-63. Accord, id. at 68.

27 "Both the congressional policy and our adherence to this principle of interpretation reflect concern that a broad ban against peaceful picketing might collide with the guarantees of the First Amendment." Id. at 63.

28 Id. (quoting NLRB v. Drivers Local Union No. 639, 362 U.S. 274, 284 (1960)). Accord, 377 U.S. at 67. The Court, like the court of appeals, noted that "[w]hen Congress meant to bar picketing per se, it made its meaning clear," id. at 68 (citing $\S 8(b)(7), 29$ U.S.C. $\S$ 158(b)(7) (1976)). 
an indication of legislative intent regarding the type of picketing in Tree Fruits, the Court concluded, was lacking. ${ }^{29}$

The Court noted that during congressional consideration of the amendments, consumer picketing had been characterized as an evil only in connection with "its use to persuade the customers of the secondary employer to cease trading with him in order to force him to cease dealing with, or to put pressure upon, the primary employer." ${ }^{30}$ Accordingly, the Court reasoned, secondary consumer picketing is unlawful only when it seeks to shut off the secondary employer's trade altogether. ${ }^{31}$ A boycott limited to the struck product, by contrast, has no effect on the secondary employer's conduct beyond possibly leading him "to drop the item as a poor seller";32 in such a case, "the union's appeal is closely confined to the primary dispute." 33

Justice Harlan, in a dissenting opinion joined by Justice Stewart, criticized the majority's interpretation as unrealistic and unsupportable. ${ }^{34} \mathrm{He}$ correctly pointed out that "[n]othing in the statute lends support to the fine distinction which the Court draws between general and limited product picketing." $35 \mathrm{He}$ also stated that the line between legal and illegal picketing as defined by the Court was "surely too refined in the context of reality" because many customers will refuse to enter a picketed store whether or not the picketing appeal is directed at only one product. ${ }^{36}$

Justice Harlan recognized that the distinction drawn by the majority is unworkable whenever the secondary employer "depends largely or entirely on sales of the struck product," ${ }^{37}$ illustrating his point with a hypothetical case.$^{38}$ Like the majority, he extensively

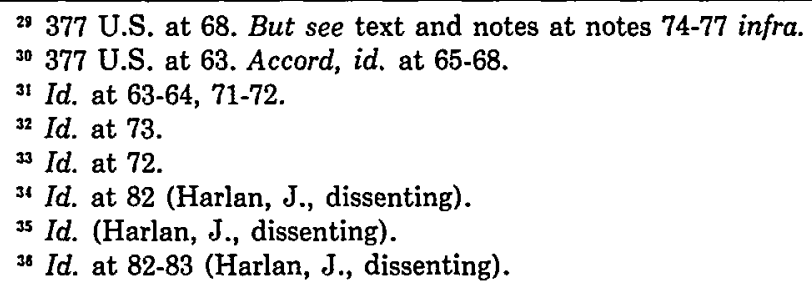

29 377 U.S. at 68 . But see text and notes at notes 74-77 infra.

${ }^{30} 377$ U.S. at 63. Accord, id. at 65-68.

3t Id. at 63-64, 71-72.

32 Id. at 73.

${ }^{3}$ Id. at 72.

"Id. at 82 (Harlan, J., dissenting).

${ }^{35}$ Id. (Harlan, J., dissenting).

${ }^{36}$ Id. at 82-83 (Harlan, J., dissenting).

Because of the very nature of picketing there may be numbers of persons who will refuse to buy at all from a picketed store, either out of economic or social conviction or because they prefer to shop where they need not brave a picket line. Moreover, the public can hardly be expected always to know or ascertain the precise scope of a particular picketing operation.

Id. See also Goetz, supra note 1 , at 702 .

${ }^{37} 377$ U.S. at 83 (Harlan, J., dissenting).

3s "If, for example, an independent gas station owner sells gasoline purchased from a struck gasoline company, one would not suppose he would feel less threatened, coerced, or restrained by picket signs which said 'Do not buy $X$ gasoline' than by signs which said 'Do 
reviewed the legislative history but concluded that Congress in 1959 intended section 8(b)(4)(ii)(B) to prohibit all consumer picketing. ${ }^{39}$ Justice Black, in a concurring opinion, agreed with Harlan's interpretation of the statute but believed that it was inconsistent with the first amendment. ${ }^{40}$

In Tree Fruits, the line between legal and illegal secondary consumer picketing was thus drawn between picketing directed only at the primary employer's product (product picketing), and that directed at the secondary employer's entire business (enterprise picketing). The Court apparently considered this an obvious dichotomy; product picketing, it said, was "poles apart" from enterprise picketing." Given the facts of Tree Fruits, where sales of the struck product constituted only a small portion of the secondary employer's business, ${ }^{42}$ the distinction indeed has a strong intuitive appeal. Its apparent ease of application in many secondary picketing situations was furthered by the development, through decisions by the Board and lower courts, of some specific requirements for permissible consumer picketing. ${ }^{43}$

not patronize this gas station.' "Id. (Harlan, J., dissenting). His hypothetical situation was strikingly similar to the facts of a case that arose ten years after Tree Fruits. Local 14055, United Steelworkers v. NLRB (Dow Chem. Co.), 524 F.2d 853 (D.C. Cir. 1975), vacated as moot, 429 U.S. 807 (1976), discussed in text and notes at notes 49, 51, 55, 59-60 infra.

${ }^{31} 377$ U.S. at 87,92 (Harlan, J., dissenting). Under this reading of the statute, Justice Harlan had to consider the potential conflict with the first amendment; he concluded that section $8(\mathrm{~b})(4)(\mathrm{ii})(\mathrm{B})$, construed as barring all secondary picketing, was not unconstitutional. Id. at 93 .

40 Id. at 76 (Black, J., concurring).

4 Id. at 70.

${ }^{12}$ Id. at 60. See text and notes at notes 53-54 infra.

43 The Board and the courts in cases following Tree Fruits developed two requirements for valid product picketing beyond the requirement that the picketing be limited to an appeal to consumers not to purchase the struck product. First, the picket signs must clearly identify the struck product. See, e.g., Bedding, Curtain \& Drapery Workers Local 140 v. NLRB, 390 F.2d 495, 502 (2d Cir. 1968) (picket signs asking customers to look for union label held not specific enough to identify struck product), cert. denied, 392 U.S. 905 (1968); Atlanta Typographical Union No. 48 (Times-Journal, Inc.), 180 N.L.R.B. 1014, 1016 (1970) (signs asking consumers not to buy products advertised by secondary employers in newspaper not specific enough to identify struck products). Second, the picket signs must inform consumers that the labor dispute is with the primary employer, not the secondary employer whose premises are being picketed. See, e.g., Hoffman ex rel. NLRB v. Cement Masons Local 337, 468 F.2d 1187, 1191-92 (9th Cir. 1972), cert. denied, 411 U.S. 986 (1973); N.L.R.B. v. Twin City Carpenters Dist. Council (Red Wing Wood Prods., Inc.), 422 F.2d 309, 314 (8th Cir. 1970); Los Angeles Typographical Local 174 (White Front Stores), 181 N.L.R.B. 384, 388 (1970).

The union has the burden of meeting these requirements, Local 248, Meat Cutters (Milwaukee Independent Meat Packers Ass'n), 230 N.L.R.B. 189, 204 (1977), which are imposed to ensure that the picketing will not result in a total boycott of the secondary employer's business. NLRB v. Twin Cities Carpenters Dist. Council, 422 F.2d 309, 314-15 (8th Cir. 1970); Atlanta Typographical Union No. 48 (Times-Journal, Inc.), 180 N.L.R.B. 1014, 1016 (1970). 


\section{Tree Fruits and Single-Product Secondary EMPloyers}

A. Applicability of the Product/Enterprise Distinction

Recent controversy over the legality of consumer picketing of single-product secondary employers ${ }^{44}$ is testimony to the problems created by the Court's adoption of an essentially unsupportable ${ }^{45}$ distinction. The dichotomy between product and enterprise picketing breaks down completely when the struck product constitutes all or most of the secondary employer's business. ${ }^{46}$ In such a situation, the two types of picketing are indistinguishable in their effect on the neutral secondary employer: the union cannot accomplish its purpose with regard to the primary employer without bringing about a substantially complete boycott of the neutral secondary employer.

Tree Fruits may be interpreted in two distinct ways, each suggesting a different approach for determining the legality of secondary picketing of a single-product employer. If the proper focus of the inquiry under Tree Fruits is on whether the boycott was limited to the struck product, then consumer picketing that is limited to an appeal to boycott the struck product is legitimate, whether the struck product is one of many or the only product sold by the secondary employer. On the other hand, if Tree Fruits is meant to protect neutral parties from disastrous or coercive collateral consequences emanating from someone else's labor problems, then consumer picketing that, if successful, will predictably result in the total cessation of a secondary employer's business is an unfair labor practice, whether or not the picket's appeal is formally limited to the struck product.

\section{B. Consequences of the "Choice": Safeco and Dow Chemical}

The Tree Fruits opinion has been interpreted as if it indeed suggested two distinct approaches; this is confirmed by the divergent results reached by the Board and the courts when faced with the problem of the single-product seller.

"E.g., Retail Store Employees Local 1001 v. NLRB (Safeco Title Ins. Co.), 101 L.R.R.M. 3084 (D.C. Cir. 1979) (en banc), cert. granted, 100 S. Ct. 658 (1980), discussed in text and notes at notes 50, 56-58, 61-62 infra; Local 14055, United Steelworkers v. NLRB (Dow Chem. Co.), 524 F.2d 853 (D.C. Cir. 1975), vacated as moot, 429 U.S. 807 (1976), discussed in text and notes at notes $49,51,55,59-60$ infra.

t3 See 377 U.S. at 82 (Harlan, J., dissenting). Justice Brennan, in his opinion for the Court in Tree Fruits, admitted that the distinction has no support in the legislative history. Id. at 64 . It is unrelated to the language of the statute, and, as interpreted by the D.C. Circuit Court of Appeals sitting en banc in Safeco, unrelated to the statutory purpose.

16 Id. at 83 (Harlan, J., dissenting). 
The first interpretation of Tree Fruits is based on the Supreme Court's statement that picketing "directed only at the struck product" 47 is lawful because such picketing is "confined to [the union's] dispute with the primary employer." 48 This approach was followed by the District of Columbia Circuit in two recent cases: Local 14055, United Steelworkers v. NLRB (Dow Chemical Co.), ${ }^{49}$ and Retail Store Employees Local 1001 v. NLRB (Safeco Title Insurance Co.). ${ }^{50}$ Both cases involved picketing of secondary employers who received most of their revenues from sales of the struck product, and in both cases the court held that the picketing did not violate the Act because it was limited to a request to consumers not to purchase the struck product. The Dow panel (and apparently the Safeco majority) believed that the principle announced in Tree Fruits was not strictly limited to the facts before the Court in that case. ${ }^{51}$

The second possible interpretation of Tree Fruits focuses on the Court's statement that "picketing which persuades the customers of a secondary employer to stop all trading with him [is] barred."52 In this context, the Court noted that in Tree Fruits the apples "were only one of numerous food products sold in the stores," "53 and that if this picketing were successful, its worst result would be that Safeway would drop the struck product "as a poor seller." ${ }_{54}$ This second approach was adopted by the Board in Dow ${ }^{55}$ and Safeco, ${ }^{56}$ and by the panel of the D.C. Circuit ${ }^{57}$ and the four dissenters to the

17. Id. at 65 .

4s Id.

1 524 F.2d 853 (1975), vacated as moot, 429 U.S. 807 (1976). In that case, the union picketed six independently owned gas stations which sold gasoline refined by the primary employer. Sales of the gasoline accounted for 60 to $98 \%$ of the gross revenues of the gas stations. Id. at 855 .

so 101 L.R.R.M. 3084 (D.C. Cir. 1979) (en banc), cert. granted, 100 S. Ct. 658 (1980). In that case, the union picketed five land-title insurance companies which received 90 to $95 \%$ of their income from sales of insurance policies of Safeco, the primary employer. Id. at 3085 n.6.

s1 524 F.2d at 857. "While the small part the struck product had in the whole of the Safeway business was not overlooked by the Court, it was not the basis for the decision." Id. at 858 .

s2 Tree Fruits, 377 U.S. at 71.

s3 Id. at 60 .

si Id. at $72-73$.

ss 211 N.L.R.B. 649, 651 (1974), enforcement denied, 524 F.2d 853 (D.C. Cir. 1975), vacated as moot, 429 U.S. 807 (1976).

st 226 N.L.R.B. 754 (1976), enforcement denied, 101 L.R.R.M. 3084 (D.C. Cir. 1979) (en banc), cert. granted, 100 S. Ct. 658 (1980).

s7 99 L.R.RM. 3300 (D.C. Cir. 1978), rev'd on rehearing en banc, 101 L.R.R.M. 3084 (D.C. Cir. 1979), cert. granted, 100 S. Ct. 658 (1980). 
en banc decision in Safeco. ${ }^{58}$ The Board in Dow reasoned that although gasoline was not the only product of the secondary employers (gas stations), their business consisted of "gasoline sales and minor items incidental thereto." 59 The Board therefore concluded that picketing directed at the gasoline would, if successful, discourage customers from dealing with the picketed gas stations at all.60 Judge Robb's dissent in Safec $0^{61}$ was based on a similar analysis: since the secondary employers derived ninety to ninety-five percent of their revenues from sales of the struck product, picketing directed at that product would necessarily be directed at the secondary employers' entire businesses. ${ }^{62}$

\section{A Unified Analysis: The Underlying Concern of Section 8(b)(4)(ii)(B) and Tree Fruits}

The divergent approaches to the single-product situation result from an assumption that Tree Fruits was meant to provide a comprehensive analytical framework for secondary consumer picketing cases. ${ }^{63}$ This assumption is plainly erroneous insofar as it leads to an invocation of the product/enterprise dichotomy. That distinction does not control in single-product cases. The statute itself should be the initial focus of attention: the intent of Congress in passing the Landrum-Griffin amendments dictates that the distinction between legal and illegal secondary consumer picketing be based on the potential effect of the picketing on the secondary employer.

\section{A. Legislative History of Section 8(b)(4)(ii)(B)}

Congress first attempted to deal with secondary boycotts in 1947 with the enactment of the Taft-Hartley Act. ${ }^{64}$ Congress appar-

ss 101 L.R.R.M. at 3094 (Robb, J., dissenting). Judges Tamm, MacKinnon, and Wilkey joined in Judge Robb's dissent.

${ }^{59} 211$ N.L.R.B. at 650. See also Duerr, Developing a Standard for Secondary Consumer Picketing, 26 LAB. L.J. 585, 589 (1975).

${ }^{60} 211$ N.L.R.B. at 651.

61 101 L.R.R.M. at 3094 (Robb, J., dissenting).

${ }^{62}$ Id. at 3095 (Robb, J., dissenting). Judge Robb also emphasized that the purpose of section 8(b)(4)(ii)(B) was to protect neutral secondary employers. Id. at 3094 .

${ }_{63}$ See Local 14055, United Steelworkers v. NLRB (Dow Chem. Co.), 524 F.2d 853, 857 (D.C. Cir. 1975), vacated as moot, 429 U.S. 807 (1976).

is Labor-Management Relations (Taft-Hartley) Act, Pub. L. No. 80-101, § 8(b)(4)(A), 61 Stat. 141 (1947) (current version at 29 U.S.C. $\& 158(b)(4)$ (1976)). Although the TaftHartley Act did not explicitly refer to secondary boycotts, it did prohibit unions from engaging in or inducing employees to engage in a strike to force an employer to "cease doing business with [another] person." Id. 
ently intended to proscribe all secondary picketing, ${ }^{65}$ but the language of the statute was ambiguous and contained loopholes that rendered the intended prohibition ineffective. ${ }^{66}$

The secondary boycott provision of the Landrum-Griffin amendments was enacted to prevent what Congress and the President perceived as union abuse of secondary picketing ${ }^{67}$ by closing up loopholes in the Taft-Hartley Act. ${ }^{68}$ The present section 8(b)(4) is the product of a compromise between the House and the Senate: the Senate bill made no changes in the law on secondary boycotts ${ }^{69}$ while the House (Landrum-Griffin) bill expanded the prohibition of the 1947 Act. $^{70}$ The Conference Committee adopted the House bill with two provisos that the Senate conferees insisted upon: ${ }^{71}$ first, the publicity proviso, which exempted all publicity other than picketing

${ }^{65}$ See, e.g., H.R. REP. No. 510, 80th Cong., 1st Sess. 43 (1947), reprinted in 1 NLRB, Legislative History of the LABOR-Management Relations Act, 1947, at 547 [hereinafter cited as Legislative History (1947)]; 93 Cong. Rec. 4198 (1947) (remarks of Sen. Taft), reprinted in 2 Legislative HistoRy (1947), supra, at 1106; 105 CONG. REc. 17,908 (1959) (remarks of Sen. Curtis) ("We all know that Congress intended to outlaw secondary boycotts in 1947."), reprinted in 2 NLRB, Legislative History of the Labor-Management Reporting aNd Disclosure ACT of 1959, at 1441 [hereinafter cited as Legislative History (1959)].

" See, e.g., United Wholesale \& Warehouse Employees Local 261 v. NLRB, 282 F.2d 824, 827 (D.C. Cir. 1960); NLRB v. International Union of Brewery Workers, 272 F.2d 817, 818-19 (10th Cir. 1959); NLRB v. Business Mach. \& Office Appliance Mechanics Conference Bd., 228 F.2d 553, 559-61 (2d Cir. 1955), cert. denied, 351 U.S. 962 (1956).

The major loophole was that the prohibition reached only union appeals to employees and thus did not comprehend appeals to consumers or to secondary employers directly. See Tree Fruits, 377 U.S. at 64. See also R. Gorman, Basic Text on Labor Law 257 (1976).

"See, e.g., 105 Cong. REc. 17,904 (1959) (remarks of Sen. Goldwater) ("Many small main street businessmen were either forced out of business or else succumbed to the union's demands."), reprinted in 2 LEGisLative HistoRy (1959), supra note 65, at 1437; id. at 17,908 (remarks of Sen. Curtis) ("secondary boycotts . . . are unfair and unjust"), reprinted in 2 Legislative History (1959), supra note 65, at 1441; id. at 3951 (remarks of Sen. McClellan) ("existing laws are inadequate to protect innocent parties from secondary boycott abuses"), reprinted in 2 LEGisLative History (1959), supra note 65, at 107; Address by President Eisenhower (Aug. 6, 1959), reprinted in 105 CoNG. Rec. A8488 (1959) (submission of Sen. Dirksen) and 2 LEGISLATIVE HISTORY (1959), supra note 65, at 1842-43.

is See 105 Cong. Rec. 17,898 (1959) (remarks of Sen. Kennedy) ("The chief effect of the conference agreement . . . will be to plug loopholes in the secondary boycott provisions of the ['Taft-Hartley Act]."), reprinted in 2 LeGisLATIVE History (1959), supra note 65, at 1431; id. at 17,904 (remarks of Sen. Goldwater) ("The [Landrum-Griffin] bill . . . closed up every loophole in the boycott section of the [Taft-Hartley Act] including the use of a secondary consumer picket line"), reprinted in 2 LEGisLattve HistoRY (1959), supra note 65, at 1437.

" S. 1555, 86th Cong., 1st Sess. (1959), reprinted in 1 Legislative HistoRy (1959), supra note 65, at 516-85. See also S. REP. No. 187, 86th Cong., 1st Sess. 70, 78-79 (1959), reprinted in 1 Legislative History (1959), supra note 65, at 466, 474-75.

${ }^{70}$ H.R. 8400,86 th Cong., 1st Sess. $\$ 705$ (1959), reprinted in 1 Legislative HistoRY (1959), supra note 65 , at $680-83$.

"See 105 Cong. REc. 17,898-99 (1959) (remarks of Sen. Kennedy), reprinted in 2 Legislative History (1959), supra note 65, at 1431. 
from the prohibition of section $8(b)(4) ;^{72}$ and second, the caveat that the right to engage in primary picketing be preserved. ${ }^{73}$

The opponents of the Landrum-Griffin amendments believed that the secondary boycott provision as enacted prohibited all secondary consumer picketing; ${ }^{74}$ three Justices in Tree Fruits, ${ }^{75}$ the National Labor Relations Board ${ }^{78}$ and commentators ${ }^{77}$ prior to the Tree Fruits decision agreed with that interpretation. This construction of section $8(\mathrm{~b})(4)(\mathrm{ii})(\mathrm{B})$ was foreclosed by the majority's pronouncement in Tree Fruits that the statute did "not reflect with the requisite clarity a congressional plan to proscribe all peaceful consumer picketing at secondary sites." 78 The prohibition as construed

${ }^{72}$ LMRDA $\S 8(\mathrm{~b})(4), 29$ U.S.C. $\$ 158(\mathrm{~b})$ (4) (1976) ("nothing contained in such paragraph shall be construed to prohibit publicity, other than picketing, for the purpose of truthfully advising the public") (emphasis added). This proviso was apparently added in response to the Senate conferees' concern that the bill would violate the first amendment. See 105 Cong. REc. 16,591 (1959) (analysis of Sen. Kennedy and Rep. Thompson), reprinted in 2 LecisLative History (1959), supra note 65, at 1708. See generally Brinker, Section $8(b)(4)(B)$ and Consumer and Informational Picketing and Publicity Other than Picketing, 23 LAB. L.J. 195, 20406 (1972); Engel, Secondary Consumer Picketing-Following the Struck Product, 52 VA. L. REv. 189, 223-25 (1966).

${ }^{73}$ LMRDA § 8(b)(4), 29 U.S.C. § 158(b)(4) (1976). See 105 Cong. REc. 17,898 (1959) (remarks of Sen. Kennedy), reprinted in 2 Legislative History (1959), supra note 65, at 1431.

" E.g., 105 Cong. REc. 17,882-83 (1959) (remarks of Sen. Morse) ("This bill . . . prohibits consumer picketing"), reprinted in 2 LEGISLATIVE HISTORY (1959), supra note 65, at 142627; id. at 17,898-99 (remarks of Sen. Kennedy), reprinted in 2 LeGISLATIVE HistoRy (1959), supra note 65 , at 1432 . The usefulness of opponents' views in statutory construction, however, is doubtful after the Supreme Court's statement in Tree Fruits:

[W] have often cautioned against the danger, when interpreting a statute, of reliance upon the views of its legislative opponents. In their zeal to defeat a bill, they understandably tend to overstate its reach. "The fears and doubts of the opposition are no authoritative guide to the construction of legislation. It is the sponsors that we look to when the meaning of the statutory words is in doubt."

377 U.S. at 66 (quoting Schwegmann Bros. v. Calvert Distillers Corp., 341 U.S. 384, 394-95 (1951)).

${ }^{75} 377$ U.S. at 92 (Harlan, J., dissenting, joined by Stewart, J.); id. at 76 (Black, J., concurring). See text and notes at notes 39-40 supra.

"B Upholsterers, Frame \& Bedding Workers Local 61 (Minneapolis House Furnishings Co.), 132 N.L.R.B. 40, 43-44 (1961), enforcement denied, 331 F.2d 561 (8th Cir. 1964) (enforcement denied on authority of Tree Fruits).

77 R. Dereshinsky, The NLRB and Secondary Boycotts 74 (1974) ("The legislative history of the Landrum-Griffin Act clearly illustrates that Congress intended to eliminate consumer picketing secondary boycotts."); R. GoRMaN, supra note 66, at 241 ("Statements by the legislative draftsmen make it clear that their object was to proscribe the secondary boycott."); Aaron, The Labor-Management Reporting and Disclosure Act of 1959, 73 HaRv. L. Rev. 1086, 1114 (1960); Cox, The Landrum-Griffin Amendments to the National Labor Relations Act, 44 Minn. L. REv. 257, 274 (1959); Comment, The Landrum-Griffin Amendments: Labor's Use of the Secondary Boycott, 45 CoRNELL L.Q. 724, 731 (1960) ("The legislative history of the new Section 8(b)(4)(ii) would seem to indicate that it was intended to prohibit secondary consumer picketing entirely, even where the picket appeals are directed solely to the distributor's customers.").

78377 U.S. at 63. 
by the Court extended only to " "isolated evils" "79 or "clearly identified abuses." ${ }^{80}$ The question thus becomes whether consumer picketing of a single-product secondary retailer falls within the limited proscription of Tree Fruits.

The legislative history supports the view that the focus of Congress in enacting the provision was on preventing the use of coercive economic pressure on neutral parties, without regard to the formal scope of a union's picketing request. Nowhere in the debates or committee reports is a distinction drawn between struck products and other goods or services of a neutral secondary employer. ${ }^{81}$

This general purpose to protect third parties unconcerned with the primary dispute is well illustrated by a colloquy between Representative Griffin, a sponsor, and Representative Brown during debate. They discussed the hypothetical case, raised by President Eisenhower in a television address, ${ }^{82}$ of a labor dispute at a furniture manufacturing company. Under the Taft-Hartley Act, Representative Griffin noted, the union could legally picket the customer entrance of a retail store selling the manufacturer's furniture. But under the Landrum-Griffin amendments, "[i]f the purpose of the picketing is to coerce or restrain the employer of that secondary establishment, to get him not to do business with the manufacturer-then such a boycott could be stopped." 83

Senator McClellan, who sponsored a bill ${ }^{84}$ very similar to the successful Landrum-Griffin provision, ${ }^{85}$ used the situation of a single-product retailer as an example of the type of coercion he

"Id. (quoting NLRB v. Drivers Local Union No. 639, 362 U.S. 274, 284 (1960)).

so Id.

B1 See id. at 64 ("this distinction was [not] expressly alluded to in the debates"). See also, id. at 83-84 (Harlan, J., dissenting).

82 Address of President Eisenhower (Aug. 6, 1959), reprinted in 105 CoNG. REc. A8488 (1959) (submission of Sen. Dirksen) and 2 Legislative HistoRY (1959), supra note 65, at 1842.

83105 CoNG. REc. 15,673 (1959) (remarks of Rep. Griffin), reprinted in 2 LEGisLATIVE HistoRy (1959), supra note 65, at 1615. The quoted sentence is one of three instances in the exchange at which Representative Griffin tied the illegality of consumer picketing to its coercive effect on the retailer. See also id. at 6667 (remarks of Sen. McClellan) ("[Secondary consumer picketing] is a form of coercion against an innocent employer, in an effort to compel the employer who has a strike on his hands to come to terms with the union."), reprinted in 2 LEGISLATIVE HISTORY (1959), supra note 65, at 1194; id. at 17,908 (remarks of Sen. Curtis) ("It will make unlawful any type of coercion or restraint where the objective is to force one person to cease doing business with another. This, of course, is the essence of the secondary boycott: coercion directed against a neutral."), reprinted in 2 LEGISLATIVE History (1959), supra note 65, at 1441; id. at 17,904 (remarks of Sen. Goldwater), reprinted in 2 LEGISLATIVE HistoRY (1959), supra note 65, at 1437.

s S. 1384, 86th Cong., Ist Sess. (1959), reprinted in 1 LEgislative History (1959), supra note 65 , at $327-29$.

ss See 2 Legislative History (1959), supra note 65, at 1912-13 (comparison of bills). 
would prohibit. He considered the position of a merchant who builds his business around farm machinery manufactured by one company; union picketing against such a merchant, said the Senator, should be banned as a secondary boycott, in part because of its effect in keeping away customers. ${ }^{86}$ The en banc majority in Safeco correctly noted that these remarks did not address precisely the issue of single-product consumer picketing, since Senator McClellan posited signs reading simply "Unfair to Labor." apparently did not contemplate the distinction between a product boycott and an enterprise boycott. Nevertheless, it is difficult to avoid the inference from his remarks that he would regard any picketing that seeks to coerce the merchant into dropping his major product or into putting pressure on the primary employer to settle his dispute as an illegal secondary boycott. "How is the merchant unfair to labor? It is simply a case of the merchant not being willing to stop handling a product which he has been handling for twenty years and on which he has built his business. That is a secondary boycott which, it seems to me, ought to be prohibited." 88

\section{B. The Proper Reading of Tree Fruits}

1. The "Isolated Evil" of Coercing Neutrals. The Supreme Court's opinion in Tree Fruits is not inconsistent with these expressions of congressional intent; the basic question in that case was to what extent the Court was willing to give effect to that intent. ${ }^{89} \mathrm{It}$

${ }^{85} 105$ Cong. Rec. 6667 (1959) (remarks of Sen. McClellan), reprinted in 2 LEGislative History (1959), supra note 65, at 1194. Cf. id. at 3951 (remarks of Sen. McClellan) (stating that the bill was aimed primarily at consumer picketing), reprinted in 2 LEGISLATIVE HISTORY (1959), supra note 65, at 1007.

${ }^{87}$ Retail Store Employees Local 1001 v. NLRB (Safeco Title Ins. Co.), 101 L.R.R.M. 3084, 3092 n.85 (D.C. Cir. 1979) (en banc), cert. granted, 100 S. Ct. 658 (1980).

\$ 105 CoNG. REc. 6667 (1959) (remarks of Sen. McClellan), reprinted in 2 LeGisLative HistoRy (1959), supra note 65, at 1194 .

89 The Court suggested that to prohibit all secondary consumer picketing could violate the first amendment, and so attributed to Congress the same concern with the constitutional issue. 377 U.S. at 63. The conclusion that consumer picketing of single-product secondary employers violates section $8(\mathrm{~b})(4)(\mathrm{ii})(\mathrm{B})$ would of necessity also present the first amendment issue, see id. at 93 (Harlan, J., dissenting), because it would impose a broader ban on picketing than was imposed by the Supreme Court in Tree Fruits. The Court in Tree Fruits held that construing the secondary boycott provision to ban only secondary consumer picketing that requested customers to stop all trading with the secondary employer was constitutional; any expansion of this construction requires reconsideration of the possibility of conflict with the first amendment.

The panel in Safeco recognized that their reading of section 8(b)(4)(ii)(B)-as prohibiting picketing of single-product secondary retailers - might raise first amendment questions. They noted that " [ $\mathrm{r}]$ ead as barring only picketing urging total consumer boycotts, . . . the statute strikes narrowly at those "inherently compulsive features" present when consumers 
is apparent that the Court's chief concern, as that of Congress in 1959 , was with protecting neutral parties, rather than with limiting the formal scope of secondary boycotts. Accordingly, consumer picketing that has the potential effect of causing a complete boycott of the secondary employer's business is illegal whether or not it is in form limited to the primary employer's products.

The Court's statement of the question presented in Tree Fruits suggests that the pivotal feature of consumer picketing is whether its appeal is limited to the struck product. ${ }^{90}$ In other passages as well, the Court used language somewhat ambiguously carrying the same suggestion: "When consumer picketing is employed only to

must cross a line." " Retail Store Employees Local 1001 v. NLRB (Safeco Title Ins. Co.), 99 L.R.R.M. 3330,3334 n.3 (D.C. Cir. 1979) (quoting Honolulu Typographical Union No. 37 v. NLRB, 401 F.2d 952, 957 n.11 (D.C. Cir. 1968)), reversed on retrearing en banc, 101 L.R.R.M. 3084 (D.C. Cir. 1979), cert. granted, 100 S. Ct. 658 (1980). The panel maintained that as long as the statute was interpreted to ban only picketing that would result in an "isolated evil" (a total boycott of a neutral secondary employer) and not as a broad prohibition of secondary consumer picketing, there would be no conflict with the first amendment. Id.

Picketing has been held to involve both communication and patrolling elements, see, e.g., Hughes v. Superior Court, 339 U.S. 460, 465 (1950); the presence of the communication aspect entitles it to some first amendment protection, see Thornhill v. Alabama, 310 U.S. $88,102(1940)$, but the presence of the patrolling component means that it is properly the subject of some regulation, see Hughes v. Superior Court, 339 U.S. at 465 . In Hughes, the Court held that picketing for illegal purposes may be prohibited without conflicting with the first amendment. Id. at 465-66. The Safeco panel cited Hughes as support for its conclusion that prohibition of the picketing in that case did not violate the first amendment. 99 L.R.R.M. at 3334 n.3. The Ninth Circuit, in Hoffman ex rel. NLRB v. Cement Masons Local 337, 468 F.2d 1187 (9th Cir. 1972), stated that "[p]icketing for unlawful ends may be restrained." Id. at 1191 n.1 (citing NLRB v. San Francisco Typographical Union No. 21, 465 F.2d 53 (9th Cir. 1972)). The Board appears to agree: "[P]icketing which constitutes proscribed pressures for an unlawful objective is not privileged by the first amendment of the Constitution and is not excused by the fact that it also may have had an informational purpose." Salem Bldg. Trades Council (Cascade Employers Ass'n, Inc.), 163 N.L.R.B. 33, 36 (1967), enforced per curiam, 388 F.2d 987 (9th Cir.), cert. denied, 391 U.S. 965 (1968). But see Tree Fruits, 377 U.S. at 76-80 (Black, J., dissenting).

In light of these cases, the Safeco panel was probably justified in concluding that its construction of section 8(b)(4)(ii)(B) did not conflict with the first amendment. The publicity proviso to that section guarantees the union a less restrictive means of publicizing its labor dispute, see note 72 supra. The relationship between the first amendment and picketing, however, is far from settled. See generally Cox, Strikes, Picketing and the Constitution, 4 VAND. L. REv. 574 (1951); Goetz, supra note 1, at 695-703; Note, The Invisible Hand and the Clenched Fist: Is There a Safe Way to Picket Under the First Amendment?, 26 Hastings L.J. 167 (1974).

so "The question in this case is whether the respondent unions violated this section when they limited their secondary picketing of retail stores to an appeal to the customers of the stores not to buy the products of certain firms against which one of the respondents was on strike." 377 U.S. at 59. But see Petition for Certiorari, Tree Fruits, reprinted in 31 U.S.L.W. 3404 (1963): "Does union's picketing at retail store, urging customers not to purchase [primary] products . . ., constitute 'threat, coercion, or restraint' . . ., absent showing that picketing inflicted any economic injury upon store." 
persuade customers not to buy the struck product, the union's appeal is closely confined to the primary dispute."11 It is important to remember, however, the factual context in which these remarks were made; the Court took care to point out that the struck product constituted but a small part of the secondary employer's business.92 Viewed in this context, there is no hint that the Court meant to promulgate a broad rule that a product boycott is legal simply because it is limited to struck products. Rather, the Court reasoned, it is legal where there is no likelihood that it can be used "to inflict injury on the secondary employer's business generally." 93

Such reasoning is fully consistent with the general theme of the Court's opinion: the aim of section $8(\mathrm{~b})(4)(\mathrm{ii})(\mathrm{B})$ is to prevent unions from putting coercive pressures on secondary employers. The "isolated evil" at which Congress was aiming, said the Court, was the use of consumer picketing "to cut off the business of a secondary employer as a means of forcing him to stop doing business with the primary employer. . . [T]he prohibition of $8(b)(4)$ is keyed to the coercive nature of the conduct, whether it be picketing or otherwise." 94 The product picketing in Tree Fruits did not present this "isolated evil."

2. The Economic Impact Test. It has been suggested that the Supreme Court's reversal of the D.C. Circuit's decision in Tree Fruits amounted to a blanket rejection of an economic impact test in secondary consumer picketing cases. ${ }^{95}$ The court of appeals had

" 377 U.S. at 72. See id. at 63 (in the case of product picketing "the union's appeal to the public is confined to its dispute with the primary employer, since the public is not asked to withhold its patronage from the secondary employer, but only to boycott the primary employer's goods. On the other hand, a union appeal to the public at the secondary site not to trade at all with the secondary employer goes beyond the goods of the primary employer"); id. at 71 ; id. at 72 n.20.

${ }^{22} I d$. at 60 .

${ }^{93}$ Id. at 72.

94 Id. at 68 (emphasis added). See id. at 63; id. at 69; id. at 68 (quoting 105 Cong. Rec. 15,673 (1959) (remarks of Rep. Griffin), reprinted in 2 LEGISLATIVE HistoRY (1959), supra note 65, at 1615). Application of this interpretation of Tree Fruits to the single-product situation leads to the conclusion that a consumer boycott of a single-product secondary employer is a violation of section 8(b)(4)(ii)(B), even though it is limited in form to a product boycott. Employers might manipulate this rule by favoring single-product distributors, who would have immunity from secondary consumer picketing, unless found to be "allied" with the primary employer, see text and notes at notes 109-117 infra. On the other hand, if Tree Fruits is interpreted as rendering legal any consumer picketing so long as it purports to be directed solely at the struck product, then a union could intentionally bring about a total enterprise boycott by dressing up its picketing as a call for a boycott of the secondary party's sole product.

${ }^{95}$ Safeco, 101 L.R.R.M. at 3092. But see Duerr, supra note 59, at 588-89. See generally Comment, Consumer Picketing: Reassessing the Concept of Employer Neutrality, 65 CaLIF. L. REv. 172, 189-95 (1977). 
held that consumer picketing violates section $8(\mathrm{~b})(4)(\mathrm{ii})(\mathrm{B})$ only if it had caused or was likely to cause substantial economic impact on the secondary employer. ${ }^{.6}$ The Supreme Court replied that a mere reduction in Safeway's sales of apples would not establish a violation, "even if this led or might lead Safeway to drop the item as a poor seller." assertions $^{98}$ that it is the coercive nature of a consumer boycott, and not a mere decline in the secondary employer's sales and purchases, that makes it illegal. Nowhere did the Court reject the possibility that illegal coercion might exist because that decline was likely to have a fatal or crippling economic impact on the secondary party..$^{99}$ Indeed, the suggestion that the Court did reject such an approach ignores the careful phrasing of the Tree Fruits holding. ${ }^{100}$

The language and reasoning of Tree Fruits, and congressional attention in 1959, were focused on the nature of the picketing's practical effect on the secondary employer. As Justice Harlan suggested in his Tree Fruits dissent, that impact is more likely to be severe when consumer picketing is used against a secondary employer whose business consists solely or predominantly of the struck product. ${ }^{101}$ If a retailer deals only in struck products, a successful product boycott will mean the complete cessation of his business. Even if sales of the struck product do not constitute his entire business, the loss of sales of his major offering may often be enough to drive him temporarily or permanently out of business notwithstanding the continued sales of his other products. Moreover, in many situations the sales of minor products are ancillary to sales of the major product-as where one product is normally bought only in conjunction with another (for example, consulting and installation services related to interior decoration products), or where the opportunity for one-stop shopping influences the consumer's choice of

\footnotetext{
" 308 F.2d at 317.

${ }^{97} 377$ U.S. at $72-73$ (emphasis added).

${ }_{98}$ See text and notes at notes 89.94 supra.

"See Duerr, supra note 59, at 588-89.

100 The Court's penultimate paragraph reads:
}

We disagree therefore with the Court of Appeals that the test of "to threaten, coerce, or restrain," for the purposes of this case is whether Safeway suffered or was likely to suffer economic loss. A violation of $\S 8(\mathrm{~b})(4)$ (ii)(B) would not be established, merely because respondents' picketing was effective to reduce Safeway's sales of Washington State apples, even if this led or might lead Safeway to drop the item as a poor seller. 377 U.S. at 72-73 (emphasis added). Both the Safeco en banc court and the Comment, supra note 95 , rely only on the second sentence.

101377 U.S. at 83 (Harlan, J., dissenting). See text and notes at notes 37-38 supra. 
stores (for example, sales of paints and brushes to do-it-yourself house painters).

Faced with such ruinous possibilities, the secondary employer will take whatever steps he can to relieve the pressure caused by the picketing. If he can, he will substitute a competing product for the struck product. It can be plausibly argued that such substitution amounts to nothing more than a straightforward market decision to drop a nonselling item. ${ }^{102}$ But realistically, any such decision will probably reflect a large degree of perceived coercion; that is, the secondary employer will reason that he had better switch suppliers because that is the only way to secure the removal of the picket lines that are destroying his business.

Moreover, single-product secondary employers frequently will not be able to substitute for the struck product at a reasonable cost. If the secondary employer is a franchisee of the primary employer, ${ }^{103}$ or if he has a large advertising investment in a brand-name product, he will usually be too strongly identified in the public mind with the struck product to allow substitution. ${ }^{104} \mathrm{~A}$ primary employer may be dominant in the secondary employer's geographical area, or competitors may have exclusive-dealership arrangements with competing retailers. Even if competing products are available, a secondary employer who has long-term or large-quantity contracts with the primary employer would have to choose between gross overinventory and liability for breach.

As a practical matter, a union will resort to secondary picketing only when the union cannot bring about a successful strike against the primary employer. ${ }^{105}$ In such a situation, the union will use secondary picketing to coerce the secondary employer into pressuring the primary employer to settle the labor dispute. When the secondary employer is a single-product seller, secondary picketing

${ }^{102}$ See text and notes at notes 32,54 supra.

${ }^{103}$ In such a situation, however, the secondary employer may not be neutral. See text and notes at notes 109-117 infra.

104 A retailer who substituted might even be subjected to consumer or government complaints of product misrepresentation or bait-and-switch tactics. In the case of durable goods, he will ordinarily be unable to offer adequate repair or warranty service on the substituted product for some time after such substitution.

105 When there is a complete shutdown of the secondary employer's major supplier, the economic impact on the single-product retailer will be virtually the same as the economic impact caused by successful secondary consumer picketing. Cf. B. MELTZER, LABOR LAW Cases, Materials, and Problems 443 (2d ed. 1977) ("Where, . . . despite a strike, [the primary employer] was able to maintain production by using replacements, supervisors, etc., secondary pressure could serve as an auxiliary strike weapon and might achieve the same result as would flow from a successful [primary] strike."). But see R. DERESHINSKY, supra note 77 , at 83 . 
is a particularly successful means for a union to achieve these ends because of the interdependence between a single-product retailer and his supplier. ${ }^{108}$ This conscription of the secondary employer on the union's side of the primary dispute is precisely what section 8(b)(4)(ii)(B) was intended to prevent, according to Tree Fruits. The "isolated evil" of secondary picketing at which Congress was aiming was "its use to persuade customers of the secondary employer to cease trading with him in order to force him to cease dealing with, or to put pressure upon, the primary èmployer. . . . [Enterprise picketing] seeks the public's assistance in forcing the secondary employer to cooperate with the union in its primary dispute."107

The preceding discussion has presented the single-product situation in its most extreme form; the phrase should not be taken too literally. Relatively few businesses sell only a product of one manufacturer, although many independent franchisees may well deal exclusively in a line of products made by a single primary employer. More often, a single-product secondary employer will be a retailer who sells several products but whose business is dominated by a single product or line of products. Adoption of an economic impact test would doubtless lead to line-drawing problems, ${ }^{108}$ but that cannot be allowed to negate the conclusion that at some point product picketing becomes illegally coercive. Focusing the inquiry on the likely economic impact of the picketing on the secondary employer seems to be the only workable approach consistent with the purpose of section $8(\mathrm{~b})(4)(\mathrm{ii})(\mathrm{B})$.

3. The Ally Doctrine. It has been suggested that the fact that a secondary employer deals predominantly in the products of the primary employer, far from making out a violation of section $8(\mathrm{~b})(4)(\mathrm{ii})(\mathrm{B})$, actually strengthens the case for the legality of the

${ }^{106}$ See text and notes at notes 101-104 supra.

${ }_{107} 377$ U.S. at $63-64$.

103 Separating the permissible from the prohibited in some cases will doubtless call for a careful weighing by the Board of disputed factual contentions. By contrast, the approach of the [Safeco en banc court] would simplify that inquiry by focusing it solely on the language of the picket signs, but in doing so would fail to achieve Congress' will as elucidated in Tree Fruits.

Petition for Certiorari, at 8-9, Retail Store Employee's Local 1001 v. NLRB, 101 L.R.R.M. 3084 (D.C. Cir. 1979) (en banc), cert. granted 100 S. Ct. 658 (1980). See also Tree Fruits, 377 U.S. at 83 (Harlan, J., dissenting).

Although line drawing may be difficult when revenues derived from sales of the struck product move away from extreme levels (for example 90\%), it seems clear that the picketing in a case like Safeco, in which the secondary employers derive 90 to $95 \%$ of their revenues from sales of the struck product (see note 50 supra), the picketing should be unlawful. 
picketing. ${ }^{109}$ Such dependence on the primary employer, the argument runs, compromises the secondary employer's status as a neutral; hence, the picketing is close to primary activity. This argument resembles the ally doctrine, under which a purportedly neutral secondary employer will be treated as standing in the shoes of the primary employer if he is "allied" with the primary. ${ }^{110}$

The contention that the secondary employer's dependence on the primary should make secondary picketing lawful, however, runs directly counter to established rules under the ally doctrine-rules reviewed, in fact, in the leading court decision upholding the legality of single-product consumer picketing. ${ }^{111}$ The court, before reaching the question whether the union's conduct violated section

109 Bennett v. Local 456, Teamsters Union, 459 F. Supp. 223, 232 \& n.19 (S.D.N.Y. 1978) (dictum); Retail Store Employees Local 1001 (Safeco Title Ins. Co.), 226 N.L.R.B. 754, 758 (1976) (Fanning \& Jenkins, Members, dissenting), enforcement denied, 101 L.R.R.M. 3084 (D.C. Cir. 1979) (en banc), cert. granted, 100 S. Ct. 658 (1980); Local 14055, United Steelworkers (Dow Chem. Co.), 211 N.L.R.B. 649, 654-55 (1974) (Fanning \& Jenkins, Members, dissenting), enforcement denied, 524 F.2d 853 (D.C. Cir. 1975), vacated as moot, 429 U.S. 807 (1976).

One commentator has suggested a general approach to consumer picketing that would "assess the lawfulness of consumer picketing by asking if its impact on the secondary em. ployer is significantly disproportionate to the degree of economic interdependence between the primary and the secondary." Comment, supra note 95, at 201. Such an approach in the single-product context would amount to a "reverse" economic impact test, allowing picketing where Congress most intended to prohibit it-specifically, where a neutral secondary employer depends entirely on revenues from sales of the primary employer's products. The suggested rule amounts to a plea that the ally doctrine be relaxed in favor of unions' right to mount a picket. Thus, the Comment posits that there should not be "a per se rule against 'total' boycotts," id. at 201, suggesting "if consumer picketing would be held lawful only so long as the pressures on the secondary are minor, it gives the union a hollow and inconsequential right," $i d$. at 190 . This statement by itself is disputable: if no apples packed by the primary employer in Tree Fruits were bought at any Safeway stores, the primary employer would be affected while the impact on each secondary would be de minimis. But more importantly, this argument ignores Congress's clear intent to protect neutral secondary employers, see text and notes at notes 64-88 supra. Thus, one court has noted:

[W] here picketing means a total boycott, one interest must plainly yield, either the Union's desire to maximize pressure on the primary employer . . . , by cutting off its markets or the neutral's desire to avoid a boycott of his entire business. In the 1959 amendments, Congress chose protection of the neutral from this sort of disruption as the interest more deserving of protection.

Honolulu Typographical Union No. 37 v. NLRB (Hawaii Press Newspapers, Inc.), 401 F.2d 952, 956 (D.C. Cir. 1968).

110 See generally R. DEREshinsky, supra note 77, at 50-72; R. GoRman, supra note 66, at 244-51; Asher, Secondary Boycotts-Allied, Neutral, and Single Employers, 52 GEo. L.J. 406 (1964); Goetz, supra note 1, at 658-68; Levin, "Wholly Unconcerned": The Scope and Meaning of the Ally Doctrine Under Section 8(b)(4) of the NLRA, 119 U. PA. L. REv. 283 (1970); Annot., 13 A.L.R. Fed. 466 (1972).

III Retail Store Employees Local 1001 v. NLRB (Safeco Title Ins. Co.), 101 L.R.R.M. 3084, 3086-87 (D.C. Cir. 1979) (en banc), cert. granted, 100 S. Ct. 658 (1980), denying enforcement on other grounds to 226 N.L.R.B. 754, 756 (1976). 
$8(\mathrm{~b})(4)(\mathrm{ii})(\mathrm{B})$, had first to ask whether the secondary employers were in fact neutral, since the protection of the statute extends only to neutral employers. ${ }^{112}$ The court unanimously ${ }^{113}$ held that the single-product retailers were not allies of their supplier and thus were entitled to the protection of section 8(b)(4)(ii)(B). Mere economic interdependence, the court held, does not make out an ally relationship; the absence of neutral status is established only by such factors as common ownership and actual integration of business operations or managerial control. ${ }^{114}$

The court's conclusion makes sense in terms of the principles erected by Congress with respect to secondary boycotts. Congress sought to insulate neutral employers from labor disputes to which they are not parties. ${ }^{115}$ Nowhere in the legislative history is there any suggestion that there are different degrees or classes of neutrality. On the contrary, the legislative history suggests that single-product retailers were precisely the sort of neutral employers Congress meant to protect. ${ }^{116}$ Likewise, the single-enterprise branch of the ally doctrine is not predicated on the concept that some neutral parties are less deserving of protection than others, but rather on the consideration that some purportedly neutral employers are actually part of the same business entity as the primary employer. ${ }^{117}$

112 Vulcan Materials Co. v. United Steelworkers, 430 F.2d 446, 451 (5th Cir. 1970); Sheet Metal Workers Local 223 v. Atlas Sheet Metal Co., 384 F.2d 101, 105 (5th Cir. 1967).

113 The appellate panel had held, 2-1, that the union's picketing violated the secondary employers' rights under section 8(b)(4)(ii)(B), Retail Store Employees Local 1001 v. NLRB (Safeco Title Ins. Co.), 99 L.R.R.M. 3330, 3332-35 (D.C. Cir. 1978); the en banc court reversed that holding by a $5-4$ vote, 101 L.R.R.M. at 3085 , 3094. In both decisions, though, the ally doctrine holding was included in the majority opinion, 99 L.R.R.M. at 3331-32; 101 L.R.R.M. at 3086-87, and agreed to in the dissent, 99 L.R.R.M. at 3335 n.3 (Robinson, J., dissenting); 101 L.R.R.M. at 3095 (Robb, J., dissenting).

i1 101 L.R.R.M. at 3087.

IIs See text and notes at notes 64-88 supra.

118 See 105 Cong. REc. 6667 (1959) (remarks of Sen. McClellan), reprinted in 2 LEgislative History (1959), supra note 65, at 1194, discussed in text and notes and notes 86 88 supra.

11 See Vulcan Materials Co. v. United Steelworkers, 430 F.2d 446, 451 (5th Cir. 1970); Sheet Metal Workers Local 223 v. Atlas Sheet Metal Co., 384 F.2d 101, 105 (5th Cir. 1967); Levin, supra note 110, at 285.

The ally doctrine will present the initial inquiry in the single-product situation. Though no ally relationship was found in either Dow or Safeco, it has been suggested that many of the single-product cases will involve sufficient economic relationships between the primary employer and the secondary seller to consider them allies. Honolulu Typographical Union No. 37 v. NLRB, 401 F.2d 952, 956 n.9 (D.C. Cir. 1968). See also Comment, supra note 95, at 195-208. 


\section{The Merged Product Doctrine}

Further support for the argument that consumer picketing of a single-product secondary employer is illegally coercive can be drawn from a close analogy to another well-established doctrine developed after Tree Fruits-the merged product doctrine. Simply stated, the rule of the merged product doctrine is that "a violation of [section 8 (b)(4)(ii)(B)] occurs when a struck product is so merged with other products that the only way for a customer to boycott the struck product is to cease patronizing the picketed place of business."'11 The rule has most often been applied when the struck product was physically integrated into the secondary product along with other, neutral components-for example, when primary lumber is built into a new house. In such cases, the Board has held (and the courts have agreed) that since the consumer cannot separate the struck product from the other components of the secondary product, picketing asking him to boycott the struck product is "tantamount to urging the prospective purchaser not to deal with the secondary employer."119 The merged product doctrine has also been invoked in cases in which the primary employer provided general business services to the secondary employer, ${ }^{120}$ or in which the primary product remains physically separate from neutral components but is not sold separately to consumers. ${ }^{121}$

11 Cement Masons Local 337 (California Ass'n of Employers), 190 N.L.R.B. 261, 266, modified, 192 N.L.R.B. 377 (1971), enforced, 468 F.2d 1187 (9th Cir. 1972).

$119 \mathrm{~K}$ \& K Constr. Co. v. NLRB, 592 F.2d 1228, 1232 (3d Cir. 1979). Accord, Twin City Carpenters Dist. Council (Red Wing Wood Prods., Inc.), 167 N.L.R.B. 1017 (1967), enforced, 422 F.2d 309 (8th Cir. 1970); Millmen Local 550 (Steiner Lumber Co.), 153 N.L.R.B. 1285 (1965), enforced on other grounds, 367 F.2d 953 (9th Cir. 1966).

${ }^{120}$ E.g., NLRB v. Building Serv. Employees Local 105 (Industrial Janitorial Serv., Inc.), 367 F.2d 227 (10th Cir. 1966) (cleaning services); Honolulu Typographical Union No. 37 (Hawaii Press Newspapers, Inc.), 167 N.L.R.B. 1030 (1967) (advertising), enforced, 401 F.2d 952 (D.C. Cir. 1968). See also Operating Eng'rs Local 139 (Oak Constr., Inc.), 226 N.L.R.B. 759 (1976) (construction of conduits for phone company); Salem Bldg. Trades Council (Cascade Employers Ass'n), 163 N.L.R.B. 33 (1967) (construction of place of business), enforced per curiam, 388 F.2d 987 (9th Cir. 1968), cert. denied, 391 U.S. 965 (1968).

121 E.g., Teamsters Local 327 (American Bread Co.), 170 N.L.R.B. 91 (1968) (bread served in or as side dishes to restaurant meals), enforced, $411 \mathrm{~F} .2 \mathrm{~d} 147$ (6th Cir. 1969). Contra, United Paperworkers Local 832 (Duro Paper Bag Mfg. Co.), 236 N.L.R.B. 1525 (1978) (paper bags used to bag groceries). The Board and court in American Bread reasoned that the struck bread lost its identity in being served as part of a meal, since " $[t]$ he customer in the restaruant either takes the meal as offered, or goes elsewhere for a meal"; hence, a purported product boycott against the bread was in reality an attempt to coerce the secondary restaurants by persuading customers to eat elsewhere. 170 N.L.R.B. at 93. The Duro Paper Bag Board distinguished American Bread, concluding that the struck bags did not lose their separate identity since cartons were sometimes (not always) available and since other customers brought their own containers. 236 N.L.R.B. at 1527. The distinction is unconvincing, 
Court and Board opinions finding single-product consumer picketing legal have correctly pointed out that the merged product doctrine can easily be reconciled with Tree Fruits. ${ }^{122}$ The merged product doctrine naturally follows from the rule that section 8(b)(4)(ii)(B) prohibits consumer picketing if (and only if) the union's appeal extends beyond the struck product to reach the neutral remainder of the secondary employer's business. ${ }^{23}$ From this perspective, the key element in a merged product situation is that the union's appeal to boycott the struck product will necessarily cause cooperating consumers to cease buying not only the struck product, but neutral components of the merged product as well. ${ }^{24}$

Although some opinions in merged product cases have argued that consumer picketing is unlawful in a merged product situation because of its effect on sales of neutral products, ${ }^{125}$ others have reasoned that such picketing is illegal because it applies coercive pressure on the secondary employer by appealing for a boycott of his entire business. Although the union's picketing may adequately identify the particular part of the secondary employer's output attributable to the primary employer, ${ }^{126}$ there is no practical way for cooperating consumers to isolate the objectionable component. Accordingly, such picketing is considered in effect a call for consumers to stop dealing with the secondary employer altogether. ${ }^{127}$ The ob-

however. Although the secondary employers did not separately charge for either the bags or the bread, customers paid for them nevertheless; in the case of bags, they were a form of overhead cost spread among all groceries sold. Certainly a customer could accept an alternative container or provide one himself (just as a restaurant customer could direct that no bread be served with his meal); the secondary employer might then reduce his purchases of the struck product in response to falling "demand," much as envisioned by the Tree Fruits Court, see text and notes at notes 32,54 supra. Nevertheless, it seems likely that when picketing calls for consumers to forgo voluntarily part of the bundle of goods and services for which they must pay, a union sympathizer will simply not patronize the picketed retailer in favor of another establishment where no such consumer sacrifice is demanded. Indeed, the stipulated facts of Duro Paper Bag include one instance of a customer refusing to buy groceries that had already been rung up and bagged because she would not accept the struck bags. Id. at 1526 .

122 E.g., Retail Store Employees Local 1001 v. NLRB (Safeco Title Ins. Co.), 101 L.R.R.M. 3084, (D.C. Cir. 1979) (en banc), cert. granted, 100 S. Ct. 658 (1980); Local 14055, United Steelworkers v. NLRB (Dow Chem. Co.), 524 F.2d 853, 860 (D.C. Cir. 1975), vacated as moot, 429 U.S. 807 (1976); Dow Chem., 211 N.L.R.B. 649, 654 (1974) (Fanning \& Jenkins, Members, dissenting).

${ }^{123}$ See text and notes at notes $32-33$ and note 43 supra.

124 See Honolulu Typographical Union No. 37 v. NLRB (Hawaï Press Newspapers, Inc.), 401 F.2d 952, 955 (D.C. Cir. 1968); Operating Eng'rs Local 139 (Oak Constr., Inc.), 226 N.L.R.B. 759 (1976).

125 See cases cited note 124 supra.

126 See note 43 supra.

127 See, e.g., K \& K Constr. Co. v. NLRB, 592 F.2d 1228, 1232-33 (3d Cir. 1979); American Bread Co. v. NLRB, 411 F.2d 147, 154 (6th Cir. 1969); Honolulu Typographical Union No. 
ject of such tactics is to coerce the secondary employer to cease buying from the primary employer, "not as a natural consequence of a falling consumer demand, but by force of the injury that would otherwise be inflicted on [his business] generally." 128

Either rationale for the merged product doctrine may apply as well to the single-product problem. ${ }^{129}$ The evil of a merged product consumer boycott may be that it takes in neutral products, ${ }^{130}$ or that its effect is identical to that of an enterprise boycott, which is also true in a single-product situation. "[In the merged product cases] the courts recognized that the holding in Tree Fruits does not apply when the union appeal necessarily asks for a total boycott of a secondary employer, and that in such instances the interests of the neutral secondary must prevail."131

The kinship between the merged product and single-product problems is best revealed in Hoffman ex rel. NLRB $v$. Cement Masons Local 337 (California Ass'n of Employers), ${ }^{132}$ an unusual case blending features of both. The secondary employer in Hoffman was the owner and developer of a housing project; the primary employer was the general contractor engaged to construct the houses. The

37 (Hawaii Press Newspapers, Inc.), 167 N.L.R.B. 1030 (1967), enforced, 401 F.2d 952 (D.C. Cir. 1968); Millmen Local 550 (Steiner Lumber Co.), 153 N.L.R.B. 1285, 1290 (1965), enforced on other grounds, 367 F.2d 953 (9th Cir. 1966).

${ }_{128}$ Honolulu Typographical Union No. 37 (Hawaii Press Newspapers, Inc.), 167 N.L.R.B. 1030, 1032 (1967), enforced, 401 F.2d 952 (D.C. Cir. 1968). Accord, NLRB v. Twin City Carpenters Dist. Council (Red Wing Wood Prods., Inc.), 422 F.2d 309, 314 (8th Cir. 1970); Teamsters Local 327 (American Bread Co.), 170 N.L.R.B. 91 (1968), enforced, 411 F.2d 147 (6th Cir. 1969); Salem Bldg. Trades Council (Cascade Employers Ass'n), 163 N.L.R.B. 33, 36 (1967), enforced per curiam, 388 F.2d 987 (9th Cir. 1968), cert. denied, 391 U.S. 965 (1968).

129 "At its extreme, if the sole output of the secondary contains the product of the primary, the prospective purchaser may of necessity cease patronizing the secondary altogether." K \& K Constr. Co. v. NLRB, 592 F.2d 1228, 1232 (3d Cir. 1979).

${ }_{130}$ This may also occur in single-product situations. When the primary employer's product is the secondary employer's major source of revenue (and customers buy other products from him only incidentally), then picketing directed at the struck product is also likely to affect sales of neutral products, see text at pp. 127-28 supra. This was true in Dow: customers came to the gas stations to buy gasoline, and purchased other products and services "incidental thereto." Local 14055, United Steelworkers (Dow Chem. Co.), 211 N.L.R.B. 649, 650 (1974), enforcement denied, 524 F.2d 853 (D.C. Cir. 1975), vacated as moot, 429 U.S. 807 (1976). Thus if customers honored the picketing appeal not to buy the gasoline, they would probably not patronize the gas station at all. See Duerr, supra note 59, at 589. The effect on neutral products may, however, be de minimis, for example, in a case in which sales of neutral products account for less than $5 \%$ of the secondary employer's revenues.

${ }^{131}$ Retail Store Employees Local 1001 v. NLRB (Safeco Title Ins. Co.), 101 L.R.R.M. 3084, 3096 (D.C. Cir. 1979) (Robb, J., dissenting), 100 S. Ct. 658 (1980). Accord, Local 14055, United Steelworkers (Dow Chem. Co.), 211 N.L.R.B. 649, 651-52 (1974), rev'd, 524 F.2d 853 (D.C. Cir. 1975), vacated as moot, 429 U.S. 809 (1976).

132468 F.2d 1187 (9th Cir. 1972). 
union alleged that the general contractor employed cement masons at below area wage standards. Because the primary employer was the general contractor rather than a subcontractor or supplier, the union treated his entire output-the houses-as the struck product, and asked customers not to purchase them. The Board accepted that characterization, ${ }^{133}$ but held that picketing was illegal under the merged product doctrine. Because the secondary employer sold only one product (the houses), the Board reasoned, the struck product (the houses) was "so merged" into the secondary employer's business (the sale of houses) that the product boycott was "tantamount to urging a boycott of his entire business." 134 In enforcing the Board's order, the court of appeals relied on merged product cases to establish that a union may not attempt to cut off all of a neutral employer's business, ${ }^{135}$ and then applied that lesson to the single-product issue: "the broad suggestion that [the primary employer's] products not be purchased . . . necessarily encompassed the entire business of . . . the neutral secondary."136

It may be argued that application of an economic impact test in this context would give special immunity to certain secondary employers who happen to rely substantially on single suppliers; indeed, in industries where exclusive dealership arrangements are

133 Cement Masons Local 337 (California Ass'n of Employers), 190 N.L.R.B. 261, 266, modified, 192 N.L.R.B. 377 (1971), enforced, 468 F.2d 1187 (9th Cir. 1972).

ist Id. In so holding, the Board confused the merged product and single-product problems. The merged product doctrine contemplates that one product (or service) is merged into a separate, and larger product (or service). Had the primary employer in the case been a cement-work subcontractor, the case would have been a typical construction merged product case in which the struck product (cement work) was integrated into the secondary employer's product (the houses). See cases cited notes 118-120 supra. Since the general contractor hired his cement masons directly, however, the struck product was his output (the houses). The houses, in turn, were the sole product of the secondary employer (the developer); there was no merger of a struck product into another product. The Board found that the struck product was "merged" into the secondary employer's business, rather than into his product, but the mechanism of that "merger" was precisely the fact that the secondary employer's entire business consisted of sales of the struck product.

135468 F.2d at 1190 (citing Honolulu Typographical Union No. 37 v. NLRB (Hawaii Press Newspapers, Inc.), 401 F.2d 952, 957 (D.C. Cir. 1968) and American Bread Co. v. NLRB, 411 F.2d 147, 152 (6th Cir. 1969)).

138468 F.2d at 1192 . The court also noted:

A union may "follow the struck product" into the secondary establishment . . . only if such secondary boycott does not attempt to influence customers to completely cease all transactions with the neutral employer. . . .

Congress determined that when a union's interest in picketing a primary employer at a "one product" site, was in direct conflict with the need to protect such neutral employers from the labor disputes of others, the neutral's interests would prevail.

Id. at $1190-91$ (emphasis in original). 
common, it may effectively deny unions a useful tool freely available to unions elsewhere. Much the same point has been raised in the merged product cases. ${ }^{137}$ Courts have responded by pointing out that section $8(\mathrm{~b})(4)(\mathrm{ii})(\mathrm{B})$ was enacted to protect neutral parties from coercive pressures stemming from labor disputes to which they are not parties. ${ }^{138}$ Hence, where the union's interest in effecting a product boycott collides with the rights of innocent secondary employers. "Congress chose protection of the neutral from this sort of disruption as the interest more deserving of protection." 139

\section{ConcLusion}

Adherence to the Tree Fruits product/enterprise dichotomy in the context of product picketing of a single-product secondary employer is misplaced. Divorced from the situation in Tree Fruits, the distinction has no relation to the language, legislative history, or purpose of section $8(\mathrm{~b})(4)(\mathrm{ii})(\mathrm{B})$; hence, the Board and the courts applying the distinction in single-product cases have reached understandably inconsistent results. Given the facts of Tree Fruits, the distinction provided a shorthand measure of the real motivating concern: excessive coercion of neutral secondary employers. An economic impact test, designed to determine whether product picketing of the secondary employer is unlawfully coercive, is consistent with the Tree Fruits decision and the legislative history of the section. Unlike the application of the product/enterprise distinction, however, use of the economic impact test will further the basic purpose of the section-the protection of neutral employers from coercive pressure.

Barbara E. Snyder

${ }^{137}$ E.g., Local 399, United Bhd. of Carpenters (K \& K Constr. Co.), 233 N.L.R.B. 718 (1977), rev'd, 592 F.2d 1228 (3d Cir. 1979). In that case, the majority stated that "in certain industries, most notably the construction industry, the fortuity that the primary employer's product usually ends up incorporated in a secondary employer's product imposes a per se broad prohibition on what would otherwise be legitimate . . . activity in most other industries." Id. at 720 . See also Goetz, supra note 1 , at 702.

${ }^{138}$ E.g., K \& K Constr. Co. v. NLRB, 592 F.2d 1228, 1234 (3d Cir. 1979) (quoting Honolulu Typographical Union No. 37 v. NLRB (Hawaii Press Newspapers, Inc.), 401 F.2d 952, 956 (D.C. Cir. 1968)). See also Goetz, supra note 1, at 702 ("[Under the merged product doctrine], purveyors of certain types of supplies and services enjoy a wider immunity to secondary consumer picketing than other employers. This seems unavoidable, however, so long as neutral retailers are to be insulated from total consumer boycotts-which seems to be the intent of Congress").

${ }^{139}$ Honolulu Typographical Union No. 37 v. NLRB (Hawaii Press Newspapers, Inc.), 401 F.2d 952, 956 (D.C. Cir. 1968). Accord, K \& K Constr. Co. v. NLRB, 592 F.2d 1228, 1239 (3d Cir. 1979). 